Kryštof Kozák

Department of North American Studies Charles University, Prague, Czech Republic (D) https:/ / orcid.org/0000-0001-8768-6428

\title{
Conflicted Cultural Memory and U.S. Foreign Policy: The "Lost Ca(u)se" of the U.S. Radar Base in the Czech Republic ${ }^{1}$
}

\begin{abstract}
This article analyzes the developments in cultural memory in Czech-U.S. relations since the end of the Cold War with a special emphasis on the heated debate about placing a U.S. radar base on Czech soil in 2008. It first describes the abrupt transformation in cultural memory related to the transition from communist rule from the transatlantic perspective. It claims that the debate about the radar base is a clear indication of the shift within cultural memory, which became much more contested, especially when compared with the previous period culminating with the Czech Republic's entry into NATO. As cultural memory is closely linked to dominant historical narratives as well as identity, the findings have serious implications for the future of the transatlantic ties in the region.
\end{abstract}

Key words: cultural memory, foreign policy, transatlantic ties, U.S.-Czech relations, radar base

\section{Introduction}

This article analyzes the role of cultural memory in Czech-U.S. relations since the Velvet Revolution of 1989. It claims that while efforts to cultivate cultural memory helped to sustain good Czech-U.S. relations, a fresh impetus is needed if cultural memory is to remain one of the significant binding ties between the two countries. This article is based on the theoretical premises connecting international politics and cultural memory, which have been elaborated in greater detail elsewhere

\footnotetext{
1 Support for this article was provided by Grant Agency of the Czech Republic as part of the research project: The Role of Collective Memory in Post-Cold War Transatlantic Relations (14-21581S). The author would like to express his gratitude for the anonymous review that helped to clarify important aspects of the paper.
} 
(Langenbacher, and Shain; Meusburger et al.; Kozák). Using diverse sources, it identifies principal instances of efforts to shape cultural memory related to CzechU.S. ties and interprets them in the wider context of bilateral relations (Glenn et al.). Methodologically, the article uses a qualitative analysis of documents related to key events in U.S.-Czech ties from a specific vantage point of the strategic uses of memory. By bringing attention to the role that memory plays in the construction of dominant historical narratives, it expands our understanding of the underlying connections between memory and politics in the specific case study of Czech-U.S. ties. Even though the Czech context is specific, the problems are nonetheless informative for comparative thinking about the uses of memory in international politics. The research paves the way for similar studies in a regional context - the case of U.S.- Polish ties had been partially addressed, but with less emphasis on the role of memory (Delaney, and Antosek). The conclusions are also relevant for the discussions about the contested narrative related to the United States on the international arena (Hard Power...; Balis, and Serfaty).

\section{Prelude: Regime change as memory change}

The Velvet Revolution of 1989 in Czechoslovakia was a watershed moment, which led to profound political, economic as well as social transformations. These were accompanied by a fundamental rethinking of history and memory in the public sphere. Before 1989, communist governments made sure that both national and world history were interpreted through the dominant Marxist paradigm - even high-quality academic books on obscure topics from ancient history needed to refer to historical materialism and the importance of class struggle at least in their introductions and conclusions. School textbooks focused disproportionately on the history of the worker's movement and the foundation and development of communism in Russia as well as in the Czech lands. Official commemorative events were tightly linked to the needs of the Communist regime, which used direct as well as indirect pressures on people to show up, especially on the May 1 (Labor Day) promenade. Other prominent official commemorative celebrations included: the liberation of Prague by the Red Army (May 9, 1945), communist take-over of the Czechoslovak government (February 25, 1948) and the communist take-over in Russia (November 11, 1917). At the same time, traumatic memories of Russian tanks arriving to halt the Prague Spring developments on August 21, 1968 or of victims of the 1950s purges were consciously repressed, as they did not fit the official narrative. Moreover, individuals who tried to preserve the awareness of these events were persecuted by the state apparatus (Kopeček).

Under the new post-communist regime, predominant thinking about history and collective memory was transformed dramatically, with an explicit rejection of the communist-sanctioned past. Efforts to reshape collective memory were specifically designed to counter the distortions and conscious omissions inherent in communist-era materials. Special emphasis was placed on the rehabilitation of the victims of the 1950s and the re-evaluation of the role of Soviet Union, which turned from "eternal brother" to principal totalitarian villain of the new narrative. Anticommunism became one of the cornerstones of the efforts to form a new cultural 
memory. The renaming of streets and subway stations was rampant in an effort to cleanse the public sphere from symbols and figures associated with the communist regime. In many instances, this trend was a reversal of the renaming that occurred during communism, e.g. the major industrial town of Gottwaldov named after first Czechoslovak communist president Gottwald got its old name "Zlín" back (Rupnik). At the same time, a more positive historical narrative was necessary to legitimize the new regime and to provide it with meaning both the past and the future (Bottici, and Challand).

In this context, the Transatlantic dimension of the political transition became relevant. Almost overnight in 1989, the United States ceased to be portrayed as the insidious imperialist power, which had been commemorated primarily in connection with the Vietnam War defeat or the Bay of Pigs invasion of Cuba. Suddenly, the U.S. became the model to be emulated, both politically and economically. In terms of the shift in cultural memory, this was manifested as early as in May 1990 by the renewed commemoration of the U.S. liberation of Pilsen. The U.S. long-term efforts to spread freedom and democracy around the globe became intertwined with the goals of the Velvet Revolution. The emergent dominant historical narrative espoused by the post-communist leaders focused on the long march of the Czechs towards freedom, democracy and prosperity, which was tragically hijacked first by the Munich Treaty and the Nazi occupation and then by the 40 years of communist totalitarian regime. Such a narrative enabled the U.S. to be recast as a helping friend, whose insistence on key principles of human rights helped to win the Cold War and thus liberate Czechoslovakia from communism (Asmus, and Vondra 204).

The interplay between political reorientation and related changes in the dominant historical narrative is remarkable, as the transformation process was mutually reinforcing - political reorientation fostered conditions for new historical narratives, which, in turn, strengthened the legitimacy of the new regime. These processes had clear political objectives - on the domestic front they discredited the former communist regime together with its policies and thus opened the way for structural reforms inspired by the U.S. On the international level, the new historical narrative was used to support the efforts of the Czech Republic to escape from the stiffening embrace of the Soviet Union and join Western structures such as the EU and NATO.

\section{The role of memory in relations between Czech Republic and the U.S. after 1989}

The relationship between the Czech Republic and the United States is defined by fundamental asymmetry, which manifests itself in many forms. The post-1989 Czech governments actively sought to get enough attention in the U.S. so that it supported its bid for NATO membership. The formal defensive alliance with the United States at the peak of its power was supposed to cure the deep trauma of a small state unable to fend for itself - the specter of the Munich treaty from 1938 and the 1968 Russian invasion were important factors, deeply ingrained both in the general public as well as with post-1989 policymakers. Working with memory and remembrance became an important tool which helped reinforce and sustain the ties between the two countries. 
One of the most prominent examples of the strategic use of memory is the historic address to a joint session of U.S. Congress by Vaclav Havel in 1990. He was speaking in the U.S. Congress as the first head of a post-communist state and the occasion was widely covered by U.S. as well as international media. Havel drew heavily on memory in the speech that set the tone for Czech-U.S. relations for the years to come: "Twice in the century, the world has been threatened by a catastrophe. Twice this catastrophe was born in Europe, and twice you Americans, along with others, were called upon to save Europe, the whole world and yourselves". The discourse of "saving Europe" is highly politically relevant, as it implies continued responsibility of the saviors, unless the effort was undertaken in vain. It also implies the gratitude of those who were saved, further strengthening the symbolic links. Havel then continued:

The first rescue mission, among other things, provided significant help to us, Czechs and Slovaks. Thanks to the great support of your President Wilson, our first president, Tomas Garrigue Masaryk, founded our modern independent state. He founded it, as you know, on the same principles on which the United States of America had been founded, as Masaryk's manuscripts held by the Library of Congress testify. ${ }^{2}$

This passage is crucial, as it not only highlights shared historical events, but also claims that both entities were founded on the same basic principles. If this were indeed the case, it would again imply the obligation of the U.S. to help its weaker member of the symbolic family within the asymmetric relation. At the end of the speech, Havel also commemorates the Declaration of Independence and Thomas Jefferson as important sources of inspiration, confirming the transatlantic linkages. On the symbolic level, it is clear that Havel tries to forge a notion of "we", which would encompass both the U.S. and Czechoslovakia, and uses selective historical references to buttress this claim.

Havel then uses strong Manichean language to frame the U.S. role in the Cold War:

All of this taught us to see the world in bipolar terms as two enormous forces - one a defender of freedom, the other a source of nightmares. ... So you may have contributed to the salvation of us Europeans, of the world and thus of yourselves for a third time. You have helped us to survive until today, without a hot war this time but merely a cold one.

The strong dichotomy of freedom vs. nightmares again implies an obligation of the U.S. to be on the side of freedom also in the future if it becomes endangered. The messianic mention of salvation serves to highlight the exceptional status of the U.S., but it is also a clear indication of flattery - tactics used frequently by weaker parties to entice stronger ones to align their mutual interests.

In seeking U.S. assistance and goodwill, Havel is able to use memory even as a veiled threat:

...most of the big wars and other conflagrations over the centuries have traditionally begun and ended on the territory of modern Czechoslovakia, or else they were somehow related to that area. Let the Second World War stand as the most recent example.

2 Full text of the speech is provided by Vaclav Havel Library, available at: http:/ / archive.vaclavhavel-library.org/Functions/download_binary.php?id=124237, last access: 15 May 2016. 
This is understandable: whether we like it or not, we are located in the very heart of Europe and, thanks to this, we have no view of the sea and no real navy. I mention this because political stability in our country has traditionally been important for the whole of Europe. This is still true today.

The implication of this passage is clear - what happens in Czechoslovakia has grave consequences for Europe and by extension also for the U.S., so the U.S. should be prepared to assist the country, to the mutual benefit of both parties. This passage is followed by a specific reference to complicated negotiations on Soviet troop withdrawals, which is an item where U.S. backing would be helpful, given the asymmetry of power between Czechoslovakia and the still-existing Soviet Union at that time. The traumatic memory of World War II informs the present, with unequivocal implications for what needs to be done. The Soviet invasion of 1968 is mentioned in the next sentence of the speech, in case somebody in the audience would miss the connection.

Overall, Havel succeeds in framing and highlighting historical events to create a compelling narrative about U.S.-Czech ties with clear implications for the present. The exclusivity of the occasion and ample media coverage created a perfect opportunity for Havel to shape the discourse of the renewed relationship for both the U.S. and Czech audience.

\section{Persuading the eagle to spread its wings - Memory in the Czech Republic's entry into NATO}

With the dominant narrative based on the U.S. as a guiding force towards freedom and democracy firmly established, the ground was firmly laid for the major geopolitical shift with long-term strategic implications, namely the Czech Republic's entry into NATO. For the post-1989 Czech political establishment as well as the majority of the population, the symbolic "return to the West" was a shared goal, which encompassed economic prosperity, individual freedoms as well as security guarantees. From the perspective of collective memory, NATO membership was a coveted goal as membership was supposed to prevent repetitions of two traumatic events in the Czech national past - the Munich Treaty of 1938 and the Soviet Invasion of 1968. In both these events the U.S. did not have any formal obligation to support Czechoslovakia, and in both cases this lack of external support ended tragically for independent Czechoslovakia.

Traumatic memories of Munich resonate highly in Czech public discourse mainly for two reasons. First is the abandonment of Czechoslovakia by its Western allies, primarily France and Great Britain at the Munich conference in September, which directly led to the disintegration of interwar independent Czechoslovakia and paved the way for the Nazi Protectorate. Secondly, it also created an opening for Soviet influence, as the traumatic memory of Munich led the Czechoslovak elites to increased cooperation with Stalin's Soviet Union, which was seen a realistic alternative external force which was capable of countering the overwhelming German influence.

The legacy of the Munich treaty as the ultimate proof of the discredited orientation on liberal democratic Western powers also played an important role in the crucial 1946 general election, where the Czechoslovak communist party won a majority 
of the votes and got into the position that allowed for the successful communist takeover of the country in February 1948. The continued relevance of Munich for the Czech society can be demonstrated by a commercially successful and critically acclaimed feature film "Lost in Munich" by renowned Czech director Petr Zelenka from 2015. The plot of the mildly absurdist fiction centers on the aged parrot of Eduard Daladier, who is brought to Prague for the 60th commemoration of the Munich treaty. Unbeknownst to the French officials, the parrot who spent its life in Daladier's study, starts saying highly offensive lines about the Czechoslovaks and praises Hitler ("Hitlerrr is superrr" is one of his favorite lines), creating a major international scandal. The film in a playful way demonstrates that the Munich trauma is alive and well all the way into the $21^{\text {st }}$ century, suggesting that Czechs are still uneasy about their relationship with the "West".

The second trauma that the entry into NATO was supposed to address is related to the crushing of the Prague Spring by the Warsaw Pact armies in August 1968. The fact that the peaceful reform process led by Czechoslovak Communist Part provoked an armed intervention was a deep shock both for the participating elites as well as the general public.

Famous photos of crowds with flowers surrounding baffled Soviet tank crews bear testimony to the level of incredulity of the Czech society about the fact that their internal reforms triggered a massive military response followed by long-term occupation. $^{3}$ Traumatic memories of the ugly aftermath of 1968 when people opposing the Soviet occupation were forced into exile, lost their jobs and positions and their children were prevented from studying at universities were vivid for the post1989 elites as well as a large part of the society. For this reason, the trauma of 1968 underscored anti-Soviet (later anti-Russian) orientation of the country throughout the 1990s. Needless to say, August 21, the day of the Warsaw Pact invasion, became duly commemorated in the media and by prominent politicians. ${ }^{4}$

The dominant narrative of both Munich and 1968 was that of a small victimized country which is unable to secure its independence vis-à-vis more powerful aggressive neighbors without effective external help. These memories served as an opening for the efforts to join NATO within the Czech society. As the U.S. emerged as the sole superpower after the disintegration of the Soviet Union in 1991, the guarantees stipulated in Article 5 were supposed to prevent any future Munich and especially any future Russian invasions. The memory of 1968 helped to sell this idea to the Czech public, which largely supported the notion of re-joining the prosperous West, including its security architecture. At the same time, no referendum on joining NATO was held, presumably to limit potentially divisive discourses on a key national security issue. ${ }^{5}$

The idea of NATO expansion faced more opposition in the U.S. and in some countries of Western Europe, where there were fears of unnecessarily antagonizing

3 Extensive digital photo collection is maintained by the Institute for the Study of Totalitarian Regimes, http://www.ustrcr.cz/cs/fotogalerie-srpen-1968-praha, last access: 1 February 2018.

4 Transcript of Vaclav Havel's speech on August 21, 1990 is available at: http://vaclavhavel.cz/showtrans.php?cat=projevy\&val=300_projevy.html\&typ=HTML, last access: 15 May 2016.

5 RAND Corporation. "The Impact of NATO Membership in the Czech Republic." Web. https://www.rand.org/natsec_area/products/czechnato.html, last access: 15 May 2016. 
Russia, which was seen as a much more important partner for the future. ${ }^{6}$ At the same time, it has been well documented that U.S. arms manufacturers linked to the Pentagon were well aware of the potential of new markets in Central Europe (Harting). Memory, both recent and distant, helped to overcome the opposition to NATO enlargement. Recent memories focused on the peaceful ending of communism in Central and Eastern Europe and highlighted the moral desert of the countries that wanted to join NATO, which would finally guarantee their security after the various traumatic incursions of the $20^{\text {th }}$ century.

Of the more distant memories, it was the Yalta conference of 1945 which helped sway a number of important Congressmen in favor of the NATO expansion. Roosevelt's conduct at Yalta was presented as a betrayal of the Central and Eastern European countries, which ended up in the Soviet sphere of influence without being consulted. NATO expansion was then presented by its proponents as a unique chance for the U.S. to make amends and correct this historical injustice. Jesse Helms, Chairman of the Senate Foreign Relations Committee, opened the committee hearings on NATO expansion with a reference to Yalta betrayal. ${ }^{7}$ According to Alexandr Vondra, who was as Ambassador part of the Czech lobbying efforts for NATO expansion in the U.S., this argument worked as a last resort, after other rational arguments failed, which indicates how powerful the memory of the past events is for the present. ${ }^{8}$

Individual memory played a role in the process, as the figure of Madeleine Albright became instrumental in the negotiation for the successful NATO expansion. Born in Prague in 1937 and forced with her family to flee the communist regime, her actions as ambassador to the U.N. and later Secretary of State demonstrated that her heritage informed her conduct to the point that Bill Clinton claimed that "Czech Republic is the only country in the world to have two ambassadors in Washington." (Zantovsky). As if to clear any doubts about her connections, Albright even wrote a book specifically about her memories of Prague (Albright).

When the deal was sealed, official speeches on the occasion of NATO expansion were laden with references to memory to justify the act. In his speech on the occasion of the entry into NATO, Vaclav Havel said on March 24, 1999 at the Prague Castle:

Sixty years after the invasion of Hitler's armies to our country and thirty years after its ambush by the Warsaw pact soldiers, even we are becoming a part of this alliance based on solidarity. Our security is becoming an indivisible part of the security of the whole Euroatlantic world, which significantly diminishes the danger that we would became spoils of some aggressor, who would decide to attack us relying on the prior knowledge of the inaction of the democratic world. ${ }^{9}$

This passage contains references both to the key traumatic memories as well as the protective arms of NATO that is supposed to save the vulnerable republic from

6 George F. Kennan. “A Fateful Error,” The New York Times, February 5, 1997.

7 Senate Foreign Relations Committee Hearing, November 1997, https://www.gpo. gov/fdsys/pkg/CHRG-105shrg46832/html/CHRG-105shrg46832.htm, last access: 15 May 2016.

Interview with Alexandr Vondra, April 21, 2016, archive of author.

9 Transcript of the speech is available at the Vaclav Havel Library website: http:/ / archive.vaclavhavel-library.org/viewArchive.php?event=19660\&itemDetail=36346, last access: 15 May 2016. 
future predators. Again, Havel makes sure that U.S. and Europe are discursively seen as one entity, the symbolic "us".

On the U.S. side, Madeleine Albright said in December 1997 during the North Atlantic Council Ministerial Meeting where she defended the decision to offer NATO membership: "These nations are accepting a fundamental change in their national identities. For decades they looked to the free world for reassurance and support in their struggles for freedom and independence." ${ }^{\prime 10}$

What is notable in this quote is the acknowledgment that the post-1989 transition required substantial rethinking of the role of the Czech Republic in the world, including the dominant historical narrative reflected in cultural memory. The link between memory and identity is clearly articulated. We should however be aware that memory is not monolithic, so the "they" in the second sentence applies only to a limited group of people, many of whom rose to power after 1989. Nevertheless, with this framing, Secretary Albright presented a dominant interpretative narrative of the past which was well suited for the current agenda under discussion.

In another speech on the topic from April 1997, Secretary Albright presented the NATO enlargement as a logical consequence of the Marshall Plan, which was presented as a highly successful example of spreading peace and prosperity throughout Europe with generous U.S. help. Based on this fact, she continues:

That [The Marshall Plan] is the unfinished business that we are taking steps to finish today. Unfinished because for 50 years, the eastern limits of European integration were determined not by the choice of free peoples, or by the interests of free nations, but by the western limits of the Red Army's advance in 1945. ${ }^{11}$

Again, the NATO enlargement is portrayed as a moral obligation, an unfinished business to address historical injustice. While the Czechs were using the alleged U.S. betrayal at Yalta when communicating with their U.S. counterparts, for Albright it was more pertinent to highlight the advance of the Red Army as she did not necessarily want to implicate President Roosevelt. While in the context of the Cold War and the problems in Vietnam, the U.S. offered little apart from rhetorical support to Czechoslovaks in 1968, the memory of the event proved useful, as it underscored the oppression by the Soviets and the resistance to it.

In presenting his decision to open NATO to enlargement, Bill Clinton employed memory on a grand scale. In his important October 1996 campaign speech in Detroit dedicated primarily to foreign policy he said:

From its very founding, our nation has stood for the idea that people have the right to control their own lives, to pursue their own dreams. In this century we have done far more than just stand for these principles. Americans have acted upon them and sacrificed for them, fought two world wars so that freedom could triumph over tyranny, then made

10 North Atlantic Treaty Organization, Statement by Secretary of State Madeleine K. Albright During the North Atlantic Council Ministerial Meeting, available at: http://www. nato.int/cps/en/natohq/opinions_25514.htm?selectedLocale=en, last access: 15 May 2016.

11 North Atlantic Treaty Organization, Speech by US Secretary of State, Madeleine Albright at the North Atlantic Council Ministerial Meeting, available at: http:/ /www.nato.int/ docu/speech/1997/s970529f.htm, last access: 15 June 2016. 
commitments that kept the peace that helped to spread democracy, that brought great prosperity to ourselves and helped to win the Cold War.

In one paragraph, Clinton is able to present a grand narrative based on the active and idealistic role of the U.S. in international affairs. References to memory serve to inform present difficult decisions. Getting to Central Europe, Clinton continued:

We have a special bond because our nation was formed from the hopes and dreams of those who came to our shores from across the Atlantic seeking religious freedom, fleeing persecution, looking for a better life. From the Pilgrims of 1620 to the Hungarian freedom fighters of 1956, whose struggle we commemorate tomorrow, they gave America the strength of diversity and the passion for freedom. Remarkable generations of Americans invested in Europe's peace and freedom with their own sacrifice. ${ }^{12}$

The notion of U.S. sacrifice on behalf of the Europeans serves to legitimize continued U.S. presence. By tying the fate of Pilgrims and the Hungarians fleeing communism, President Clinton rhetorically creates a common ground defined through "passion for freedom". Similarly to Havel, his evocation of memory places the countries of Central Europe and the U.S. together in the symbolic "us" category, thus discursively supporting the close ties.

The successful 1999 NATO expansion marks the pinnacle of the post-Cold War transatlantic ties, and it was accompanied by successful framing of public memory on both sides of the Atlantic (Phillips 5). In the U.S., the peaceful transition of Central Europe and its integration into global capitalist economy served as an important vindication of its own positive role in the world, reinforcing the memories of the U.S. as a historical champion of freedom. (Ouellette, and Weiss). In the Czech Republic, the memory of 1968 played a crucial role in generating support for entry into NATO. The common overarching theme of historical struggles for freedom provided a joint framework of reference that helped deliver the final outcome.

Even after joining NATO, references to memory continued to be relevant within Czech-U.S. ties. The dominant memory of the U.S. as forceful liberator fighting oppressive regimes played an important role in the decision by President Havel to support U.S. military action in Kosovo and Serbia in 1999. His justification was, to a great extent, based on the historical notion of spreading democracy and human rights.

The international community, namely the Alliance, decided not to watch silently any longer. ... Milosevic refused to sign the peace agreement, resisted against the entire democratic world, which then had no other choice left, in the interest of the protection of human lives and stopping human suffering, than to intervene. I understand this solution to be extreme but, due to the given circumstances, quite necessary. The Czech Republic, as a member of the North Atlantic Alliance, is aware of its commitments resulting from its membership. ${ }^{13}$

12 North Atlantic Treaty Organization, Transcript of the Remarks by President W. J. Clinton to People of Detroit, available at: http://www.nato.int/docu/speech/1996/s961022a. htm, last access: 15 June 2016.

13 Statement on the situation in Kosovo, Prague, March 25, 1999 http:/ /www.vaclavhavel.cz/showtrans.php?cat=projevy\&val=110_aj_projevy.html\&typ=HTML, last access: 15 June 2016. 
Havel rhetorically summons the idea of the entire democratic world facing evil dictators who are trampling on human rights of their subjects. The Alliance then becomes the force that is capable of delivering transformative change, and Czech Republic is a proud member drawing inspiration from its own recent struggles against an oppressive regime. At the same time, already in 1999 a critical discourse was present in Czech politics and the media, criticizing the NATO bombing of civilian targets in Serbia. ${ }^{14}$

The positive memory of the U.S. played a role also in the diplomatic crisis connected with the U.S. invasion of Iraq in 2003. At the height of the tensions between U.S. on the one side and Germany and France on the other, Vaclav Havel became one of the prominent signatories (together with Tony Blair, Leszek Miller or Peter Medgyessy) of the widely circulated "Letter of Eight", which evoked the memory of the past to support the U.S. position on Iraq and thus bolster the transatlantic link in the time of crisis:

Today more than ever, the transatlantic bond is a guarantee of our freedom.

We in Europe have a relationship with the United States which has stood the test of time.

Thanks in large part to American bravery, generosity and far-sightedness, Europe was set free from the two forms of tyranny that devastated our continent in the 20th century: Nazism and Communism. ${ }^{15}$

The underlying rationale seemed to be that by its past actions, the U.S. somehow earned the right to pursue interventionist policies. The memory of past victories served as a justification for the current political position, which was based on the firm attachment to the transatlantic link.

\section{Trouble with the radar - death of a fairytale}

When the administration of George W. Bush asked the Czech government to host a U.S. army base with a powerful radar facility which would be part of an integrated missile shield, it was consistent with the dominant narrative of U.S.-Czech ties based on the cultural memory which led to the Czech Republic's entry into NATO. However, the offer generated substantial controversy and became one of the most discussed topics in the Czech media in the years 2007 and 2008. Despite vigorous public relation efforts of the special government representative for the promotion of the radar, Tomáš Klvaňa, the initiative failed to get the support of the majority of the public. ${ }^{16}$ Even though it was not a necessary precondition for the construction of the radar base, vocal public opposition delayed the project and contributed to

14 Jiří Pehe, Postoje českých politiků a občanů ke kosovské krizi [Attitudes of Czech politicians and citizens to the crisis in Kosovo], 7.04.1999. Web. http://www.pehe.cz/ clanky/1999/postoje-ceskych-politiku-a-obcanu-ke-kosovske, last access: 15 June 2016.

15 Letter of Eight, transcript available at: http://news.bbc.co.uk/2/hi/europe/2708877. stm, last access: 15 June 2016.

16 Cervenka, Jan, Občané o americké radarové základně v ČR - červen 2009 [Citizens on American Radar Base in CR - June 2009], Center for Research on Public Opinion, 2009, available at: http://cvvm.soc.cas.cz/media/com_form2content/documents/c1/a3406/f3/ 100679s_pm70424.pdf, last access: 15 June 2016. 
the decision of the new Obama administration to cancel the radar base. This leads to the important question of what happened in terms of the dominant narrative on U.S.-Czech ties within the Czech society. How come the overwhelming support for NATO membership did not translate into the support of the U.S. radar base? Did the strategic use of memory play any part in the process?

Based on the published material of the special government representative for the promotion of the radar base, we can see that memory played an important role in argumentation, even though the main focus of the argumentation was on the threat presented by missiles from Iran and North Korea. On the official DVD supporting the radar base, the historical trauma of Munich and the Soviet invasion are prominently mentioned by Prime Minister Mirek Topolánek and famous Czech movie director Jiří Menzel. The need to defend ourselves serves as the discursive link, connecting the traumatic historical experiences with the need to rise to the occasion in the present. ${ }^{17}$

Apart from official, government-sanctioned efforts, the radar also had active and vigorous grass-roots supporters. Many of them were ostensibly motivated by the instinctive anti-Russian sentiment going back to the trauma of 1968 and saw any military linkage with the U.S. as the only credible bulwark against Russian threat. In a telling scene from the documentary Czech Peace which focused on the radar debate, Ivan "Magor" Jirous, a prominent eccentric dissident poet berates young anti-radar activists on the grounds that they are too naïve and have no idea about the mortal danger of the "Bolsheviks". ${ }^{18}$

The powerful anti-Russian card, however, could not be fully utilized by the official campaign, as the agreed-upon official U.S. as well as Czech justification did not mention Russia as the reason for the construction of the base in order not to further antagonize Kremlin leaders. At the same time, it was the historical fear of Russia (and not the somewhat virtual threat Iranian or North Korean missiles attacking Europe) that motivated most of the ardent grass-roots radar supporters. In Poland, which was supposed to host missile interceptors, the government became more straightforward in emphasizing the symbolic geopolitical significance of the project, which was subsequently more popular than in the Czech Republic. For the purposes of this paper, it is important to note that the Polish memory of the destructive Russian intervention and occupation goes much deeper than in the Czech case. ${ }^{19}$

Reading through the articles and speeches relevant for the Czech radar debate, the main focus was on the threat of Iranian missiles, health and environmental risks of the facility or the merits of pacifism. When promoting the radar in the Czech Parliament, Prime Minister Topolánek used a historical analogy with the placement of U.S. missiles in Europe: "The argument that we do not need the radar is a purely pacifistic ideology, similar to the one that was heard in European

17 Proti raketám [Against Rockets], Office of the special government representative, 2008, available at: https:/ /www.youtube.com/watch?v=AZZT5Sspdy4, last access: 15 June 2016.

18 Tomáš Klusák, Filip Remunda, Český mír [Czech Peace], 2010, available on Youtube at: https:/ / www.youtube.com/watch?v=TZ1lzA9v_-s, last access: 15 June 2016.

19 Adam Taylor, Why Poland Wants a Military Base, Washington Post, June 13, 2014, available at: https://www.washingtonpost.com/news/worldviews/wp/2014/06/03/whypoland-wants-a-u-s-military-base/, last access: 15 June 2016. 
countries in the 1960s and 70s - or directly after the war - when much bigger U.S. bases were constructed on European soil." ${ }^{20}$ When discussing the issue in Parliament, Tomáš Dub, MP from the governing Civic Democratic Party, provided the historical context sanctioned by the proponents of the U.S. radar base. After claiming that the building of the base is a logical third step after entry into NATO and EU, he said:

Even in the period of the First Republic [1918-1948], in the period of renewed statehood, Czech politicians tried hard to incorporate Czechoslovakia into Western democratic structures. The year 1938, whose sad anniversary we have just witnessed, and even more the year 1948 showed that the level of integration into Western democracies was insufficient. Forty years of totalitarian rule including Soviet occupation confirmed this. Therefore I repeat that our country with a sensitive position in the middle of Europe needs to constantly strengthen its security guarantees, and the building of the U.S. radar base is one of the few strategic decisions that we have in this regard. ${ }^{21}$

Foreign Minister Karel Schwarzenberg in the same parliamentary debate reinforced the positive memory of the U.S. to support his pro-radar position: "The transatlantic bond was a guarantee of safety for Western Europe in the second half of the $20^{\text {th }}$ century, and its continuation and strengthening is necessary for the whole Europe today. United States is an ally, which has always stood on our side in the critical moments of our history." 22

The crucial question about welcoming the U.S. military presence remained in the background of the discussion. The pro-radar camp did not want to be seen as advocating a subservient "protectorate" mentality as would invoke both the Nazi Protectorate of Bohemia and Moravia as well as the memories of the infamous invitation letter signed by selected Communist party leaders that was used as a pretext for the presence of Soviet troops. For this reason, the focus was on common defense against serious external threats.

The anti-radar camp also kept the topic of the relations with the United States in the background of their protest, as the leaders were aware that overly direct attacks could alienate the general public and be too reminiscent of the efforts of Communist governments to present the U.S. in a bad light. It was therefore easier to attack weak points in the official position or frame the debate in a normative anti-war and anti-military context. Cultural memory helped as a rich tradition of subversive antimilitary sentiment dating to the figure of good soldier Svejk authored by Jaroslav Hasek existed. Compulsory military service under communism for all males that ended only in 1998 was not very popular, either. The anti-radar camp appropriated this memory and linked it to U.S. militarism and general distrust to any army

20 Czech Government, Transcript of the speech of the Prime Minister Topolanek, 29.10.2008, available at: http://www.vlada.cz/cz/za-premierem-a-vladou/proc-potrebujeme-radar--stenozaznam-proslovu-predsedy-vlady-k-poslancum-29-10-2008--44508/, last access: 15 June 2016.

21 Parliament of the Czech Republic, Transcript of the debate available at: http:/ /www. psp.cz/eknih/2006ps/stenprot/039schuz/s039097.htm, last access: 15 June 2016.

${ }_{22}$ Parliament of the Czech Republic, Transcript of the debate available at: http:/ /www. psp.cz/eknih/2006ps/stenprot/039schuz/s039102.htm, last access: 15 June 2016. 
in general. ${ }^{23}$ These discursive maneuvers notwithstanding, the relation with the U.S. loomed large over the debate.

A remarkable episode helps clarify that despite the official rhetoric focusing on virtual Iranian missiles, the debate was in fact about the relations towards the United States. Prominent Czech country singer Jan Vyčítal was an admirer of the U.S. culture already under communism. Famous for his protest song about the U.S. liberation of Pilsen (which was a taboo subject under communism), he wanted to support the pro-radar camp. The outcome was a song and a video clip "Hello, radar, welcome" which utilized the memory of the Pilsen liberation and connected it to the present debate. The clip is heavy on Willis Jeeps and female models sporting automatic rifles and bikinis adorned with U.S. flags. ${ }^{24}$ The tune of this song is taken from a famous communist song "Good Day, Major Gagarin" celebrating the Soviet hero. The outcome was a bizarre cultural product that laid bare the desire of the author to have as much of the U.S. as close to home as possible. Unfortunately, its clear political message coupled with the naive portrayal of the U.S. were heavily reminiscent of the Communist propaganda extolling the eternal friendship with the Soviet Union based on the memory of liberation from Nazi Germany by the Red Army. What should have ended as a rather awkward footnote entered diplomatic history, as the Minister of Defense at that time, Vlasta Parkanova (herself an amateur singer), became so fascinated with the song that she recorded a duet version with Mr. Vyčital and gave the record as an official gift to George W. Bush on his visit to Prague in 2008. ${ }^{25}$ This effort to lure the powerful and superior U.S. to help save the country is a clear indication of post-colonial mentality based on selective memories of the glorious past.

For the post-1989 political elites that brought the country to NATO, the distrustful reaction of the general public came as an unwelcome surprise, as it ran counter to the dominant narrative based on the memory of the U.S. as a positive, liberating force in Czech history. Suddenly the decision not to hold a referendum on NATO membership seemed prudent, as it might have proved more divisive than expected. Even the PR campaign whose self-proclaimed focus was to "educate" the public did little to change the negative attitudes, despite employing the most famous Czech celebrities mixed with security and health experts. The success of the anti-radar camp is remarkable if we take into account the fact that the NGO leading the loose coalition of anti-radar activists was run primarily by two inexperienced self-proclaimed humanists with limited resources. The main opposition parties at the time, the Communist Party and the Social Democratic Party were also critical of the radar, albeit partly for opportunistic reasons when they saw how unpopular the project was with the public. The whole anti-radar movement was also constantly harassed as naïve, unpatriotic, dangerous, traitorous, pro-terrorist or accused of being puppets of the

23 Ne základnám magazine, October, 2009, p.2, available at: http:/ / www.nezakladnam. cz/files/Nulte_cislo.pdf.

24 Jan Vyčítal, Dobrý den prapore $z$ hvězd a pruhů [Good day to you, banner with stars and stripes], 2007, available at: https:/ /www.youtube.com/watch?v=zaP3jyANF10, last access: 15 June 2016.

25 Jan Gazdík, Parkanová zpívá o radaru [Parkanova sings about the radar], MF Dnes, June 5, 2007, available at: http://www.army.cz/scripts/detail.php?id=9353, last access: 15 June 2016. 
Kremlin - harsh charges in the highly securitized milieu of the global war on terror and of Russian intervention to Georgia. ${ }^{26}$ In spite of this criticism, public support could not be easily swayed. Blatant anti-Americanism was still rare in the anti-radar campaign, as it blended with traditional Czech cultural anti-militaristic attitudes not aimed at any particular country. Fear of the re-militarization of the Central European region played a role as well.

Even if the placement of the radar base in the Czech Republic at first seemed to fall neatly into the post-1989 narrative based on the positive memory of U.S., the project was derailed to a great extent also by negative public opinion, despite the heavy investment of political capital of the government coalition. I suggest that dynamic developments with respect to collective memory of the United States played an important role in this process. The principal website of the anti-radar movement www.nezakladnam.cz (meaning "no to bases") featured a list of post-1945 military interventions by the United States, which directly aimed at shifting collective memory by presenting an alternative dominant narrative related to U.S. history. The document, self-described as a scientific study, begins with an introduction which explicitly states that "U.S. has always pursued its own, purely selfish economic and (geo)political interests, and for this reason it has never hesitated to topple foreign governments, orchestrate political murders or support oppressive dictatorships, only if these are sufficiently pro-market and pro-American." 27 The introduction is followed by a chronological list of 37 U.S. operations abroad after 1945, each with a brief commentary that is provided to highlight the negative aspects of the U.S. operation. The list begins with the nuclear bombardment of Japan in 1945. The event is interpreted as a cynical show of force aimed primarily at intimidating the Soviet Union and thus marking the beginning of the Cold War. The list also mentions Panama in 1946 (founding of the School of the Americas), the Korean War, Iran in 1953, Guatemala in 1954, Indonesia in 1958, Haiti in 1959, Ecuador in 1960, Cuba in 1960, Brazil in 1962, Iraq in 1963, Zaire in 1964, Vietnam in 1964, Dominican Republic in 1965, Indonesia in 1965, Greece in 1967, Bolivia in 1971, Uruguay in 1972, Chile in 1973, Nicaragua in 1979, Afghanistan in 1979, El Salvador in 1980, Honduras in 1980, Guatemala in 1982, Grenada in 1983, Libya in 1986, Iran in 1988, Panama in 1989, Iraq in 1991, Somalia from1 992 to 1995, Iraq in 1998, Sudan in 1998, Colombia in 1999, Afghanistan in 2001, Venezuela in 2002, Iraq in 2003. The last entry is dedicated to Iran with a question mark, suggesting that it might be next in line. Even though the nature of the cited events is quite diverse, the commentary always focuses on the negative role the U.S. government played in each particular instance.

26 See for example Adam B. Bartoš, Mluvčí Ne základnám sympatizuje s teroristickou organizací [Speaker of the no bases expresses sympathy for terror organization], idnes.cz, March 20, 2008, available http:/ / zpravy.idnes.cz/mluvci-ne-zakladnam-sympatizuje-s-teroristickou-organizaci-prq-/domaci.aspx?c=A080319_165313_domaci_adb, last access: 15 June 2016.

27 Předběžný seznam amerických intervencí do roku 1945 [Preliminary list of American interventions since 1945], available at: http:/ / www.nezakladnam.cz/cs/969_predbezny-seznam-americkych-intervenci-od-roku-1945, last access: 15 June 2016. 
There is an infographic at the bottom of the list which places each intervention on the global map (see Picture 1).

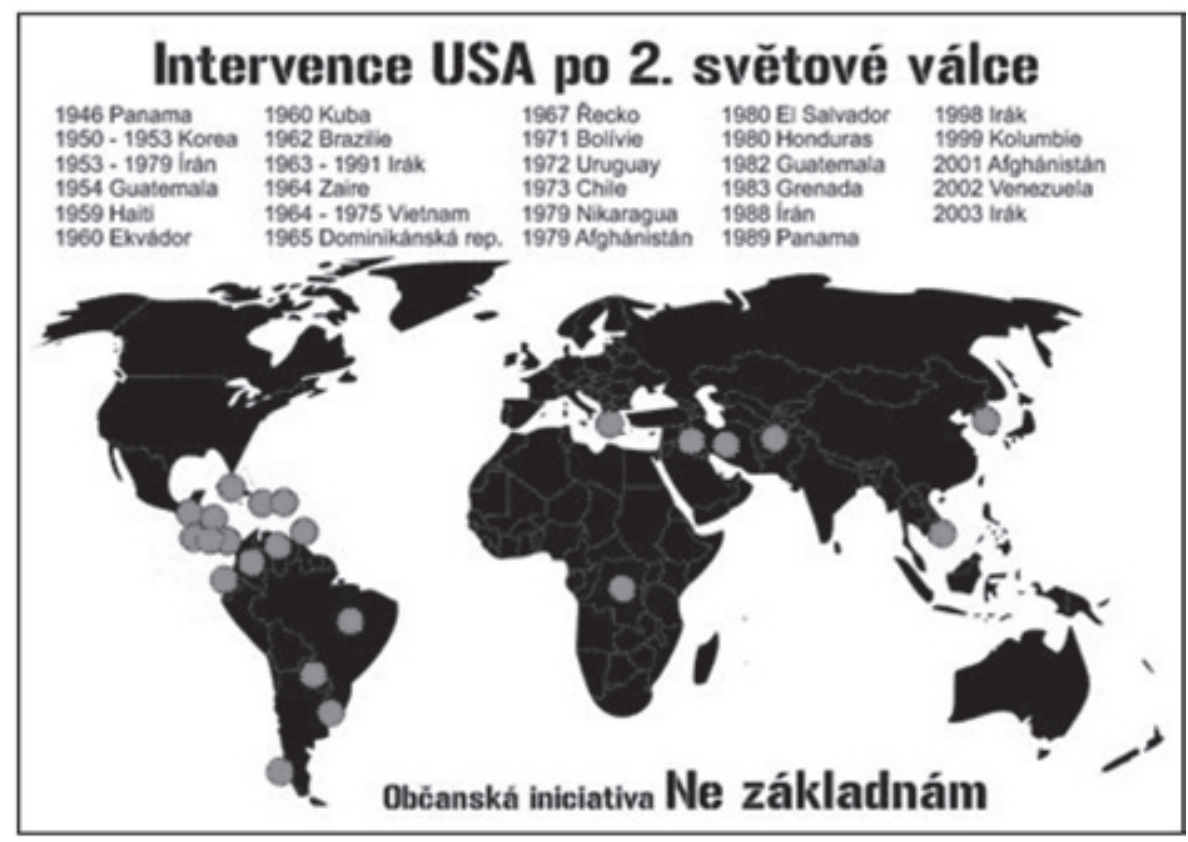

Picture 1: Interventions by the U.S. after World War II. Source: www.nezakladnam.cz.

The purpose of the document is to create a simple alternative interpretation of U.S. history and also to provide a specific spin on events that the reader has in his or her memory. The technique of selective focus is used quite efficiently, as all the events indeed did occur, which gives credit to the entire endeavor. The events are followed by one-sided interpretation with the purpose of supporting the original thesis about immoral motives behind U.S. foreign policy. The aspect of immorality was particularly important, as it directly challenged the dominant memories of the U.S. in the Czech Republic as the champion of freedom, liberty and human rights. This conscious manipulation of history and memory serves a specific goal with respect to a current transatlantic issue being discussed. The fact that nobody is signed as the author makes it appear like the official statement of the anti-radar movement. The logo of the movement is also embedded in the infographic.

When searching for the original inspiration, there is but one reference on the site, leading to a copy of an article published by freelance U.S. journalist William Blum in Z Magazine in $1999 .{ }^{28}$ The Czech site contains a slightly modified and updated version. The referenced website, thirdworldtraveler.com, does not provide any information other than to be

28 William Blum, A Brief History of U.S. Interventions: 1945 to the Present, Z magazine, June 1999, available at: http://www.thirdworldtraveler.com/Blum/US_Interventions_ WBlumZ.html, last access: 15 June 2016. 
an archive of articles and book excerpts that seek to tell the truth about American democracy, media, and foreign policy, and about the impact of the actions of the United States government, central banks, global financial and trade institutions, transnational corporations, and the corporate media, on democracy, social and economic justice, human rights, and war and peace, in the Third World, and in the developed world. ${ }^{29}$

Amid quotes by Buddha and Orwell about the necessity to search for the truth, it lists a mix of critical to outright conspiratorial materials primarily by U.S. authors.

$\mathrm{Z}$ magazine, which is the original venue of publication of the source document, is part Z Communications, a media outlet in Massachusetts dedicated to progressive causes and prominently featuring the critical writings of Noam Chomsky or Howard Zinn. Books by William Blum have been published in the U.S., and his volume Rogue State: A Guide to the World's Only Superpower, published by Common Courage Press in 2000, became famous after Osama Bin Laden recommended it in one of his video addresses. It is therefore somewhat ironic that when looking for critical versions of U.S. history, Czech movement draws inspiration primarily from a U.S. source criticizing its own government. The struggle to shape collective memory of the United States thus has a clear transnational aspect. By guaranteeing the freedom of speech, the U.S. government unwittingly provides cover for alternative interpretations shaping the memories about the U.S. role in the world that are ultimately damaging U.S. foreign policy goals. Even though it is not possible to claim that it was the primary reason, the simplified damning alternative history of the U.S. contributed to the shifting perspective about the U.S. in the Czech Republic.

When we try to interpret the evolving changes in collective memory with respect to Czech-U.S. ties, we can observe a gradual dying out of the fairytale image of the U.S. that was created primarily in the 1990s in the atmosphere of the euphoria from the fall of communism, which was coupled with deep anti-Russian sentiments based on the living memory of the 1968 invasion. Positive memories of the U.S. as a vanquisher of totalitarian regimes led to unrealistic expectations about the primarily moral motives of U.S. foreign policy spreading human rights and freedom around the world. This development coincides with general trends in Europe, where antiAmerican sentiments ran high especially during George W. Bush's presidency (53\% of Europeans regarded the U.S. as a threat to world peace in 2007). ${ }^{30}$

In this sense, the memory of the invasion of Iraq and its aftermath tolled the death of the fairytale image of the U.S., as it created a serious cognitive dissonance for all those who supported the U.S. position based on the memories of selective positive historical precedents. The Iraq invasion also gave additional credit to those who tried to construct the dominant memory of the U.S. in critical terms by adding a significant dot into their simplified (and at times manipulative) frameworks (Balis, and Serfaty 14). Public opinion polls confirm that the Iraq War was viewed negatively by the majority of the Czech public. ${ }^{31}$ Opponents of the radar could thus con-

29 Third World Traveler, www.thirdwolrdtraveler.com, last access: 15 June 2016.

30 Pew Research Center, America's Image in the World: Findings from the Pew Global Attitudes Project, March 14, 2007, available at: http://www.pewglobal.org/2007/03/14/ americas-image-in-the-world-findings-from-the-pew-global-attitudes-project/, last access: 15 June 2016.

31 Center for Research on Public Opinion, Postoje české veřejnosti k plánovanému útoku 
nect the recent memory of Iraq with other past events, thus creating a more plausible general interpretation.

The death of the fairytale view of the United States is not confined to the Czech Republic, but also has reverberations in the United States, where a group of prominent politicians such as Madeleine Albright and thinkers like Susan Rice supported the agenda of using the U.S. might to spread human rights and democracy. The memory of the Czechoslovak Velvet Revolution, where a peaceful, pro-American regime change occurred with widespread popular support, was instrumental for the sustained efforts in this direction. The key transatlantic linkage is provided by the memory and legacy of Vaclav Havel, who serves as an important symbol of such policies. The unveiling of Havel's bust in U.S. Congress in 2014 was a major commemorative event that underscored his symbolic role in the U.S. political imagination. $^{32}$

However, the more recent memories of the Iraq invasion cast all subsequent U.S. efforts at regime change into a much more problematic light of pragmatic interests hypocritically disguised in moralistic terms. To add to this, popular mass protests toppling oppressive regimes during the Arab Spring initially favored by the U.S., did not end as smoothly as the Velvet Revolution, casting further doubts about using the memory of Havel's moral imperatives as a source for U.S. foreign policy. Obama's opening towards Cuba is in this respect a direct reversal of long-term Czech-U.S. cooperation with helping Cuban dissidents with the distant hope of bringing down the regime (Pojar). The optimistic historical narrative of the U.S. spreading freedom and democracy throughout the world, where people are anxiously waiting to be liberated, thus became more of a memory than an effective principle guiding foreign policy in the U.S. context.

\section{Conclusions: Shifts in Memory Signal Challenges to Come}

By focusing on the case of the putative radar base in the U.S., the article showed how the dominant form of the post-1989 memory of the U.S. in the Czech Republic started to compete with other, more critical narratives. This development has far-reaching consequences for both the Czech Republic and the U.S., and presents a useful framework for similar research in a regional context. In the Czech Republic, the struggle over dominant memory of the U.S. serves as a proxy war between political forces supporting the Western orientation of the country and those who look East for inspiration. While the entry into NATO and the EU (with continued popular support) ${ }^{33}$ was supposed to cement the Western orientation of the country,

\footnotetext{
v Iráku [Attitudes of Czech public on the planned attack on Iraq], 10.02.2003, available at: cvvm.soc.cas.cz/media/com_form2content/documents/c1/.../100166s_pm30129.pdf, last access: 15 June 2016.

32 Maria Recio, Billy Gibbons sings blues, for Czech hero, Havel, on Capitol Hill, McClatchy, November 20, 2014, http:/ / www.mcclatchydc.com/news/politics-government/congress/article24776596.html, last access: 15 June 2016.

33 Lukáš Jiráček, Jak Češi vnímají NATO a roli USA? [How Czechs view NATO and the role of USA], 2014, available at: http://www.cicar.cz/article/show-article/jak-cesi-vnimajinato-a-roli-usa, last access: 15 June 2016.
} 
subsequent developments demonstrated how naïve or premature such thinking was. In a memory-related incident, the first popularly-elected president, Milos Zeman, was the only sitting president of a European Union country to attend the Victory Parade commemorating the Red Army in Moscow in 2015. When Andrew Shapiro, U.S. Ambassador to Czech Republic cautiously commented on this fact, he was officially banned from the Prague Castle. ${ }^{34}$ In this context it is not surprising that the memory and legacy of Vaclav Havel is contested, and his pro-American and prointerventionist views are part of the criticism. (At the same time, there is a strong informal group of thinkers and artists who vigorously defend his legacy.) The appeal of strong, nationalist leaders uniting their respective countries when facing chaotic and disruptive transnational forces became seductive again. At the same time, recent negative memories such as the Iraq invasion or Guantánamo displace the positive ones centered on the positive liberating potential of the U.S. For this reason it is essential to get beyond the simple black-and-white memories either abhorring the U.S. or uncritically praising it. Only then will it become clear what memories of the U.S. can serve as inspiring guiding lights and what memories are best to use as caveats for the future.

For the United States the implications are clear - its image became much more contested in the Czech Republic since the start of the Global War on Terror, which can be demonstrated also on the changes with respect to the memory of the United States in the public discourse. This fact has negative geopolitical implications, as became evident in the debate about the U.S. radar base. Contested cultural memory also signifies a contested dominant narrative about the role of the U.S. in the world within the Czech society. While some measure of realistic correction was in order in the Czech case, U.S. policymakers and diplomats should be aware of the fact that the positive memories of liberation from Nazism and communism are now competing with more problematic recent memories, which also serve to reinterpret the more distant past. This opens up space primarily for the renewed influence of Russia. To counter that, U.S. should look for fresh ideas about working with cultural memory and shaping its historical narrative presented abroad.

\section{Bibliography}

Albright, Madeleine. Prague Winter: A Personal Story of Remembrance and War, 1937-1948, Harper Perennial, 2010.

Asmus, Ronald D., and Vondra, Alexandr. "The Origins of Atlanticism in Central and Eastern Europe." Cambridge Review of International Affairs, 18, 2, 2005: 203-216, https://doi. org/10.1080/09557570500164439.

Balis, Christina V., and Serfaty, Simon. Visions of America and Europe. September 11, Iraq and Transatlantic Relations. Washington, D.C.: Center for Strategic and International Studies Press, 2004.

Blum, William. "A Brief History of U.S. Interventions: 1945 to the Present." Z magazine, June 1999. Web. 15 June 2016. http:/ / www.thirdworldtraveler.com/Blum/US_Interventions_ WBlumZ.html.

34 Sean Carney, Czech President Clashes with U.S. Ambassador Over Russia, The Wall Street Journal, April 5, 2015. 
Bottici, Chiara, and Challand, Benoit, Imagining Europe. Myth, Memory and Identity, Cambridge: Cambridge University Press, 2013.

Carney, Sean. "Czech President Clashes With U.S. Ambassador Over Russia." The Wall Street Journal, April 5, 2015.

Cervenka, Jan. “Občané o americké radarové základně v ČR - červen 2009” [Citizens on American Radar Base in CR - June 2009]. Center for Research on Public Opinion, 2009. Web. 15 June 2016. http:/ /cvvm.soc.cas.cz/media/com_form2content/documents/c1/a3406/ f3/100679s_pm70424.pdf.

Delaney, Kate, and Antoszek, Andrzej. "Americanization and Anti-Americanism in Poland: A Case Study, 1945-2006". Global Perspectives on the United States. Pro-Americanism, Anti-Americanism, and the Discourses Between. Edited by Virginia R. Dominguez, and Jane C. Desmond. Urbana: University of Illinois Press, 2017: 73-92, https://doi.org/10.5406/ illinois/9780252040832.003.0008.

Gazdík, Jan. "Parkanová zpívá o radaru” [Parkanova sings about the radar]. MF Dnes, June 5, 2007. Web. 15 June 2016. http:/ / www.army.cz/scripts/detail.php?id=9353.

Glenn, John K. et al. Czech-American Relations: A Roadmap for the Future. Prague: Prague Center for Transatlantic Relations, 2015.

Ilgen, Thomas L. (ed.) Hard Power, Soft Power and the Future of Transatlantic Relations. Ashgate Publishing Group, 2006.

Jiráček, Lukáš. Jak Češi vnímají NATO a roli USA? [How Czechs view NATO and the role of USA], 2014. Web. 15 June 2016. http://www.cicar.cz/article/show-article/ jak-cesi-vnimaji-nato-a-roli-usa.

Klusák, Tomáš, and Remunda, Filip. Český mír [Czech Peace], 2010. Documentary available on Youtube. Web. 15 June 2016. https:/ / www.youtube.com/watch?v=TZ1lzA9v_-s.

Harting, William D. "The Hidden Costs of NATO Expansion." World Policy Institute Issue Brief, 1998. Web. 1 February 2018. http:/ / www.worldpolicy.org/projects/arms/reports/ natocost.html.

Havel, Václav. "Speech to U.S. Congress," February 21, 1999. Vaclav Havel Library. Web. 15 May 2018. https:/ / archive.vaclavhavel-library.org/File/Show/158451.

Havel, Václav. "Speech on the occasion of Czech entry into NATO," March 24, 1999. Vaclav Havel Library. Web. 15 May 2018. http:/ / archive.vaclavhavel-library.org/viewArchive.ph p? event=19660\&itemDetail=36346.

Kennan, George F. "A Fateful Error,” The New York Times, February 5, 1997.

Kopeček, Michal. "From the Politics of History to Memory as Political Language: Czech Dealings with the Communist Past after 1989." Forum Geschichtskulturen, Czechia. Web. 16 December 2013. http:/ / www.imre-kertesz-kolleg.uni-jena.de/index.php?id=519\&l=0.

Kozák, Kryštof. “Collective Memory In Transatlantic Relations: In Search For The Ties That Bind." Acta Universitatis Carolinae. Studia Territorialia 15, 1-2, 2015: 65-84, https://doi. org/ /10.14712/23363231.2015.80.

Langenbacher, Eric, and Shain, Yossi. Power and the Past: Collective Memory and International Relations, Georgetown University Press, 2010.

North Atlantic Treaty Organization. "Speech by US Secretary of State, Madeleine Albright at the North Atlantic Council Ministerial Meeting," May 29, 1997. Web. 15 June 2016. http:/ / www.nato.int/docu/speech/1997/s970529f.htm.

North Atlantic Treaty Organization. "Transcript of the Remarks by President W.J. Clinton to People of Detroit," October 22, 1996. Web. 15 June 2016. http://www.nato.int/docu/ speech/1996/s961022a.htm.

Meusburger, Peter, Heffernan, Michael, and Wunder, Edgar. Cultural Memories. The Geographical Point of View. Springer Netherlands, 2010, https://doi.org/10.1007/ 978-90-481-8945-8.

Ouellette, Megan E., and Weiss, Tomáš. “'This Marvelous Symbol of Our Identity': The Czech 
Republic in American Practical Geopolitics." Geopolitics, 20, 2, 2015: 267-286. https:/ / doi. org/10.1080/14650045.2014.964862.

Pehe, Jiř́i. "Postoje českých politiků a občanů ke kosovské krizi" [Attitudes of Czech politicians and citizens to the crisis in Kosovo], 7.04.1999. Web. 15 June 2016. http://www. pehe.cz/clanky/1999/ postoje-ceskych-politiku-a-obcanu-ke-kosovske.

Phillips R. Kendall (ed.). Framing Public Memory, University of Alabama Press, 2004.

Pojar, Tomáš. "Czech-American Relations and Support of Liberal Democratic Forces Around the Globe." Glenn, John K. et al. Czech-American Relations. A Roadmap for the Future. Prague: Prague Center for Transatlantic Relations, 2015: 80-86.

RAND Corporation. "The Impact of NATO Membership in the Czech Republic." Web. 15 May 2016. https://www.rand.org/natsec_area/products/czechnato.html.

Recio, Maria. "Billy Gibbons sings blues, for Czech hero, Havel, on Capitol Hill." McClatchy, November 20, 2014. Web. 15 June 2016. http://www.mcclatchydc.com/news/politicsgovernment/congress/article24776596.html.

Rupnik, Jacques. "The Politics of Coming to Terms with the Communist Past. The Czech Case in Central European Perspective." Tr@nsit online 22, 2002. Web. 25 May 2011. http:/ / archiv.iwm.at $/$ index.php?option=com_content\&task=view\&id=286\&Itemid $=464$.

Taylor, Adam. "Why Poland Wants a Military Base," Washington Post, June 13, 2014. Web. 15 June 2016. https://www.washingtonpost.com/news/worldviews/wp/2014/06/03/ why-poland-wants-a-u-s-military-base/.

Zantovsky, Michael, "In Search for Allies: Vaclav Havel and the Expansion of NATO." World Affairs, November 2014. Web. http://www.worldaffairsjournal.org/article/ search-allies-vaclav-havel-and-expansion-nato. 